\title{
Secondary amenorrhoea associated with Chlamydia trachomatis infection
}

\author{
ATTILA TOTH, LAURENCE B SENTERFIT, AND WILLIAM J LEDGER \\ From the MacLeod Laboratory for Infertility, the Department of Microbiology, and the Department of \\ Obstetrics and Gynaecology, New York Hospital, New York, USA
}

SUMMARY Chlamydia trachomatis was isolated from the ovaries of a 39-year-old married woman who presented with secondary amenorrhoea. Treatment with doxycycline was given and menstruation resumed spontaneously.

\section{Introduction}

Chlamydia trachomatis is a common cause of nongonococcal urethritis in men. ${ }^{1}$ The organism has also been isolated in a wide variety of genital tract conditions including salpingitis, ${ }^{2}$ peritonitis, ${ }^{3}$ endometritis, ${ }^{4}$ and lately perihepatitis. ${ }^{5}$ This report describes a case of oophoritis from which Chlamydia trachomatis was isolated and in which secondary amenorrhoea resolved after antibiotic treatment.

\section{Case report}

A 39-year-old white woman, gravida 11 , para 2 (1 living), abortions 9 ( 1 induced), was initially seen because of secondary amenorrhoea. She wanted to become pregnant if her endocrine problems could be resolved. An initial analysis of semen from her husband was normal: the sperm count was 88 million $/ \mathrm{ml}$, motility $3 / 60 \%, 75 \%$ oval forms. He had a history of gonorrhoea treated with intramuscular penicillin in 1956. His initial symptoms had promptly subsided but an episode of mild dysuria occurred a few weeks later and cleared spontaneously. His wife had used an intrauterine device at the time of the marriage when she was 26 years old and this was removed six months later when the couple decided to attempt a pregnancy. Between 1969 and 1979 she had had 11 pregnancies, the outcome of these is summarised in table I. During these years she had had recurring vaginitis and bladder infections. At the same time she noticed profound changes in her menstrual pattern. The

Address for reprints: $\operatorname{Dr}$ A Toth, MacLeod Laboratory for Infertility, New York Hospital, 525 East 68th Street, New York, NY 10021, USA

Accepted for publication 20 September 1982 length of her menstrual bleeding, which had been five days with copious bright red blood, diminished to one day, and frequently only brownish staining occurred. Severe cramps that formerly characterised the first day of her menstruation had completely disappeared. In the 18 months before she was seen by us she stopped having spontaneous periods and only responded to increasing dosages of clomiphene. In the six months before we saw her human menopausal gonadotropin (Pergonal) combined with human chorionic gonadotropin (HCG) was given. The patient stopped taking the Pergonal-HCG and had no periods for four months when she was first seen by us.

After the initial consultation medroxyprogesterone (Provera) $10 \mathrm{mg}$ was given twice a day for five days. One day of brownish staining followed early in May. Hormone tests, performed 10 days later, included oestradiol, follicle-stimulating hormone, luteinising hormone, and prolactin (table II). A progesterone assay was performed 10 days later. The tests were repeated a month later after a second Provera slough. Endometrial biopsies were performed 17 days after the Provera treatment (fig 1a). The husband's seminal fluid and the endometrial biopsy specimens were cultured for Mycoplasma spp, aerobic and anaerobic bacteria, and Chlamydia trachomatis (table II). In June 1981 a diagnostic laparoscopy and biopsy of the ovaries were performed. Through the laparoscope both ovaries appeared pearly white and had a rubbery consistency with no sign of recent ovulation or a corpus luteum. Several corpora albicantea were present. Both tubes were patent, the uterus and other pelvic structures appeared normal, and there was no gross evidence of infection. The ovarian biopsy specimen was examined histologically (fig 2) and a portion of tissue was cultured for Mycoplasma spp, aerobic and anaerobic bacteria, and $C$ trachomatis. The only 
TABLE I Outcome of 11 pregnancies before the doxycycline treatment

\begin{tabular}{|c|c|c|c|c|}
\hline Pregnancy & Date & Gestation (weeks) & Fetal-maternal outcome & Diagnostic procedures and treatment \\
\hline 1 & 1969 & 28 & $\begin{array}{l}\text { Premature rupture of membranes, neonatal } \\
\text { death }\end{array}$ & \\
\hline 2 & 1970 & 12 & Spontaneous abortion & $\begin{array}{l}\text { Endometrial biopsy showing luteal-phase } \\
\text { defect, normal serum progesterone }\end{array}$ \\
\hline 3 & 1970 & 16 & Spontaneous abortion & Progesterone + prednisone, normal HSG \\
\hline 4 & 1971 & 37 & $\begin{array}{l}\text { Premature rupture of membranes, live male, } \\
\text { endomyometritis }\end{array}$ & $\begin{array}{l}\text { Conception after a 10-day tetracycline course } \\
\text { for dermatological condition, ampicillin and } \\
\text { cephalotin intravenously for postpartum } \\
\text { endomyometritis }\end{array}$ \\
\hline 5 & 1972 & 6 & Induced abortion & \\
\hline 6 & 1975 & 17 & Incompetent cervix, spontaneous abortion & Advised for cerclage, normal karyotype \\
\hline $\begin{array}{l}7 \\
8\end{array}$ & $\begin{array}{l}1976 \\
1977\end{array}$ & $\begin{array}{l}11 \\
12\end{array}$ & $\begin{array}{l}\text { Spontaneous abortion } \\
\text { Spontaneous abortion }\end{array}$ & $\begin{array}{l}\text { Endometrial biopsy and serum progesterone } \\
\text { showing luteal-phase defect, increasing dos }\end{array}$ \\
\hline 9 & 1978 & 8 & $\begin{array}{l}\text { Spontaneous abortion followed by dilatation } \\
\text { and curettage }\end{array}$ & of clomiphene \\
\hline 10 & 1979 & 7 days & Spontaneous abortion & Beta-subunit \\
\hline 11 & 1979 & 11 days & Spontaneous abortion & Beta-subunit \\
\hline
\end{tabular}

HSG $=$ hysterosalpingogram

TABLE II Cultures for Chlamydia trachomatis and hormone studies before and after doxycycline therapy

\begin{tabular}{|c|c|c|c|c|c|c|c|c|}
\hline \multirow[b]{2}{*}{ Date } & \multicolumn{3}{|c|}{ Culture results: } & \multicolumn{5}{|c|}{ Hormones } \\
\hline & $\begin{array}{l}\text { Seminal } \\
\text { fluid }\end{array}$ & $\begin{array}{l}\text { Endometrial } \\
\text { biopsy }\end{array}$ & $\begin{array}{l}\text { Ovarian } \\
\text { biopsy }\end{array}$ & $\begin{array}{l}F S H \\
(\mathrm{miu} / \mathrm{ml})\end{array}$ & $\begin{array}{l}L H \\
(\mathrm{miu} / \mathrm{ml})\end{array}$ & $\begin{array}{l}\text { Prolactin } \\
(n g / m l)\end{array}$ & $\begin{array}{l}\text { Estradiol } \\
(\mathrm{pg} / \mathrm{ml})\end{array}$ & $\begin{array}{l}\text { Progesterone } \\
(\mathrm{ng} / \mathrm{ml})\end{array}$ \\
\hline \multicolumn{9}{|c|}{$\begin{array}{l}\text { Before doxycycline } \\
\text { treatment: }\end{array}$} \\
\hline May 1981 & + & + & & 12 & 15 & 11 & 108 & 0.4 \\
\hline June 1981 & + & & + & 11 & 14 & 15 & 96 & 0.64 \\
\hline \multicolumn{9}{|c|}{ After doxycycline } \\
\hline July 1981 & - & - & & 7 & 13 & 5 & 475 & $21 \cdot 0$ \\
\hline August 1981 & - & - & & 10 & 11 & 4 & 392 & $19 \cdot 0$ \\
\hline
\end{tabular}

$+=$ positive; - = negative. $\mathrm{FSH}=$ follicle-stimulating hormone; $\mathbf{L H}=$ luteinising hormone.

organism isolated was $C$ trachomatis (fig 3 ). Both the woman and her husband were then treated with doxycycline (table II); the patient received intravenous doxycycline $100 \mathrm{mg}$ twice daily for six days followed by $100 \mathrm{mg}$ twice a day for three weeks as an outpatient; the husband received $100 \mathrm{mg}$ twice daily for 30 days. The patient resumed spontaneous menstruation in July 1981, and repeat hormone studies and endometrial biopsies were performed in July and August (table II and fig 1b). Culture for $C$ trachomatis was repeated on the endometrial biopsy and the seminal fluid and produced no growth (table II). Her last menstrual period began on 11 October 1981, and a beta-subunit assay performed on 16 December 1981 confirmed the presence of an intrauterine gestation which was compatible with the dates. At the end of June 1982 the patient delivered a healthy female infant.

\section{LABORATORY INVESTIGATIONS}

For cultivation and identification of $C$ trachomatis McCoy cells purchased from Microbiological Associates (MA Bioproducts, Walkersville, Maryland, USA) were used. These were inoculated by centrifugation of the specimens on to the cells treated with cyclohexamide following the procedure of Schachter and Dawson. ${ }^{6}$ Inoculated cells were $\bar{Z}$ incubated at $35^{\circ} \mathrm{C}$ for 65 hours. Inclusions in cells were identified as chlamydia by direct immunofluorescence using fluorescein isothiocyanatelabelled rabbit anti-Chlamydia trachomatis gamma globulin. Background staining was reduced by prestaining the preparations with rhodamine-labelled normal rabbit gamma globulin. This procedure reduced or eliminated the non-specific staining due to charge effect. Mycoplasma cultures were $\frac{D}{O}$ performed as described ${ }^{7}$ and Port-a-Cul reduced media (BBL, Cockeysville, Maryland, USA) were $\mathbb{N}$ used for transporting specimens for aerobic and anaerobic bacteria studies.

\section{Discussion}

This patient represents a case of unsuspected genital tract infection with Chlamydia trachomatis. The histological and microbiological findings provided the evidence of the site of the infection. Since ovarian biopsies were performed under sterile conditions $\frac{\rho}{\mathbb{D}}$ through the laparoscope and the biopsy specimens were handled separately contamination with 

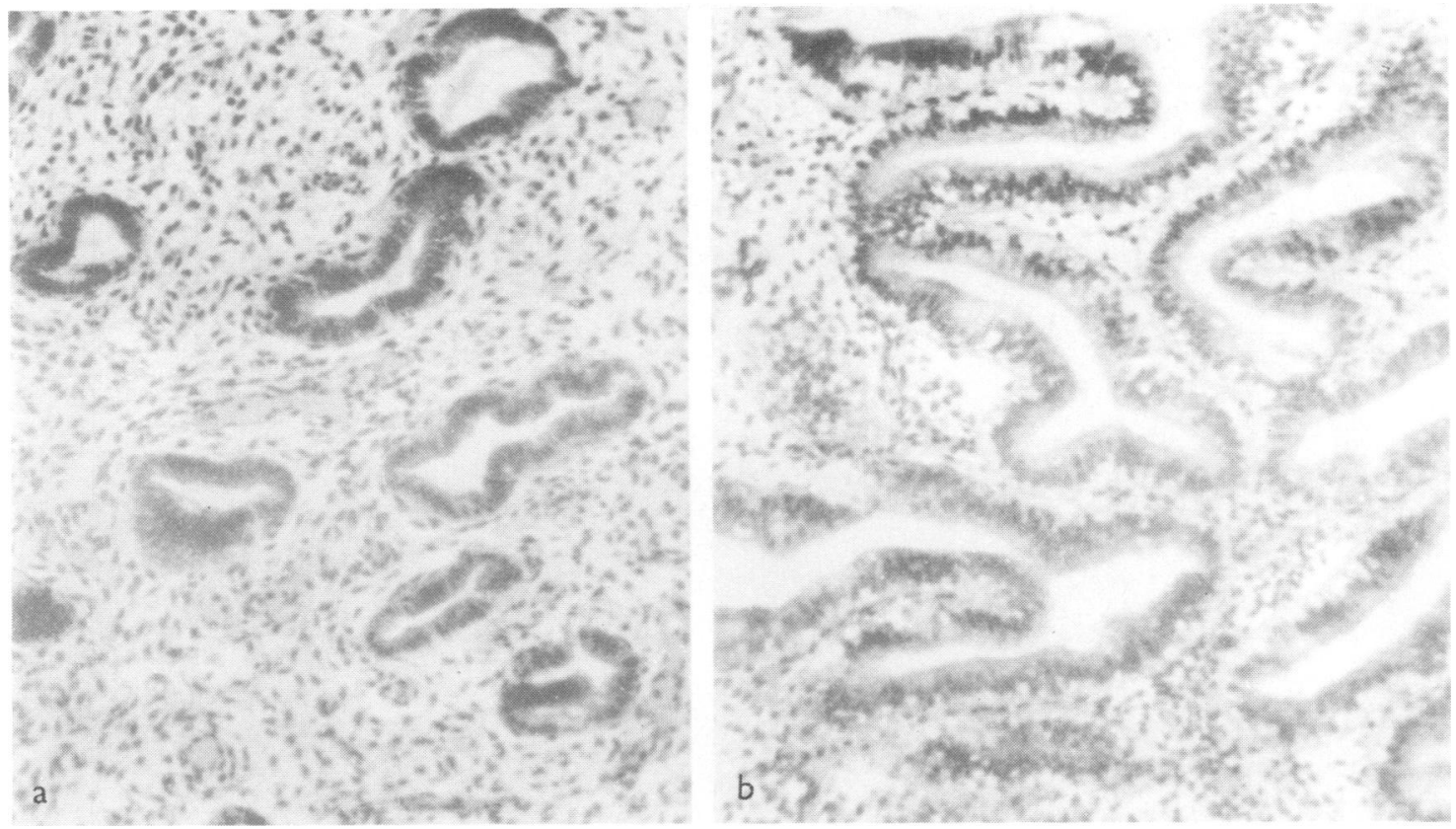

FIG 1 Endometrial biopsy specimens on day 17 of menstrual cycle (a) before doxycycline treatment (note inactive endometrial glands) and (b) after treatment. (Note well-developed secretory changes). Haematoxylin and eosin, original magnification $\times 250$.

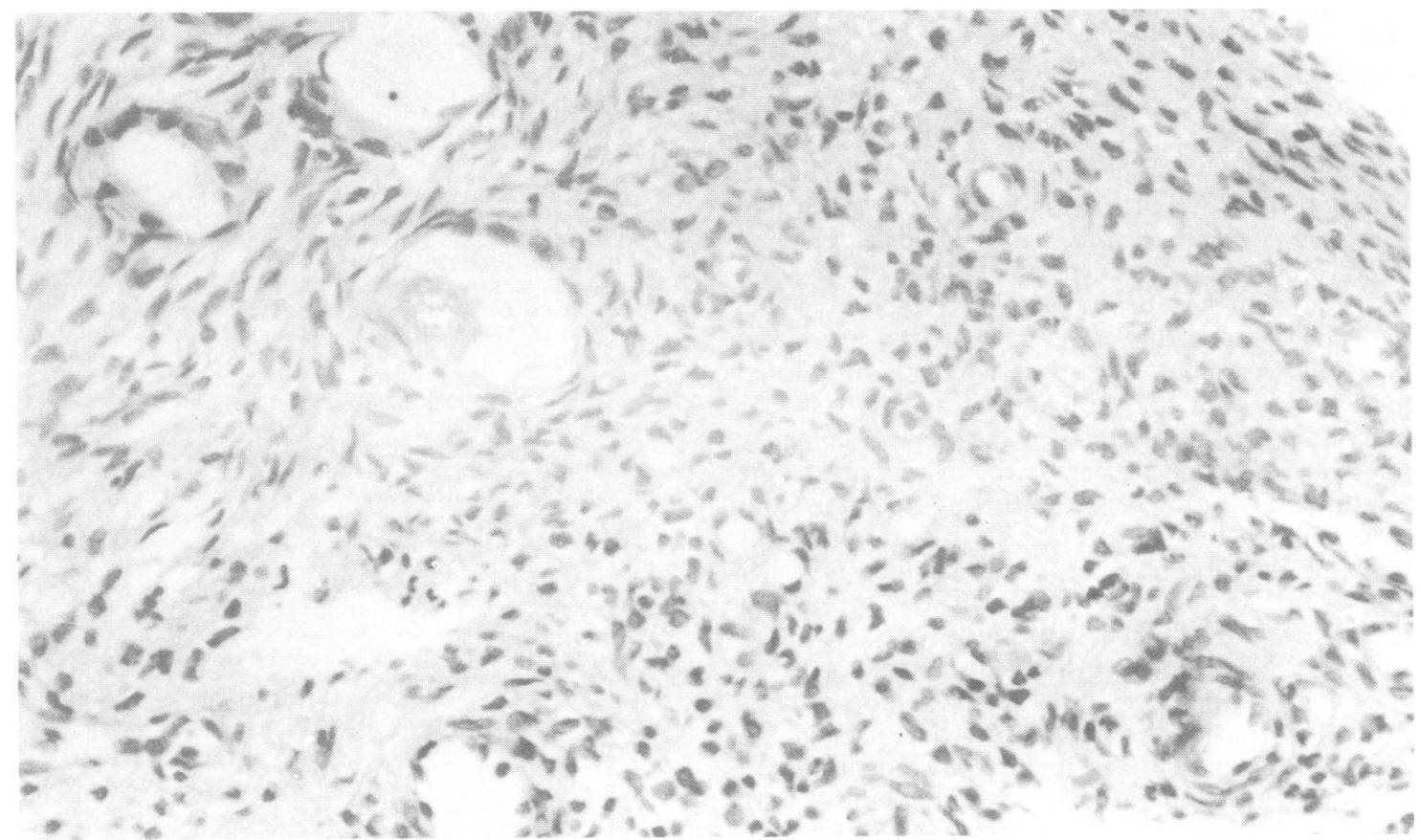

FIG 2 Secretion of ovarian biopsy specimen showing diffuse acute and chronic inflammatory cell infiltrate with pronounced reduction of primordial follicles. Haematoxylin and eosin, original magnification $\times 250$. 


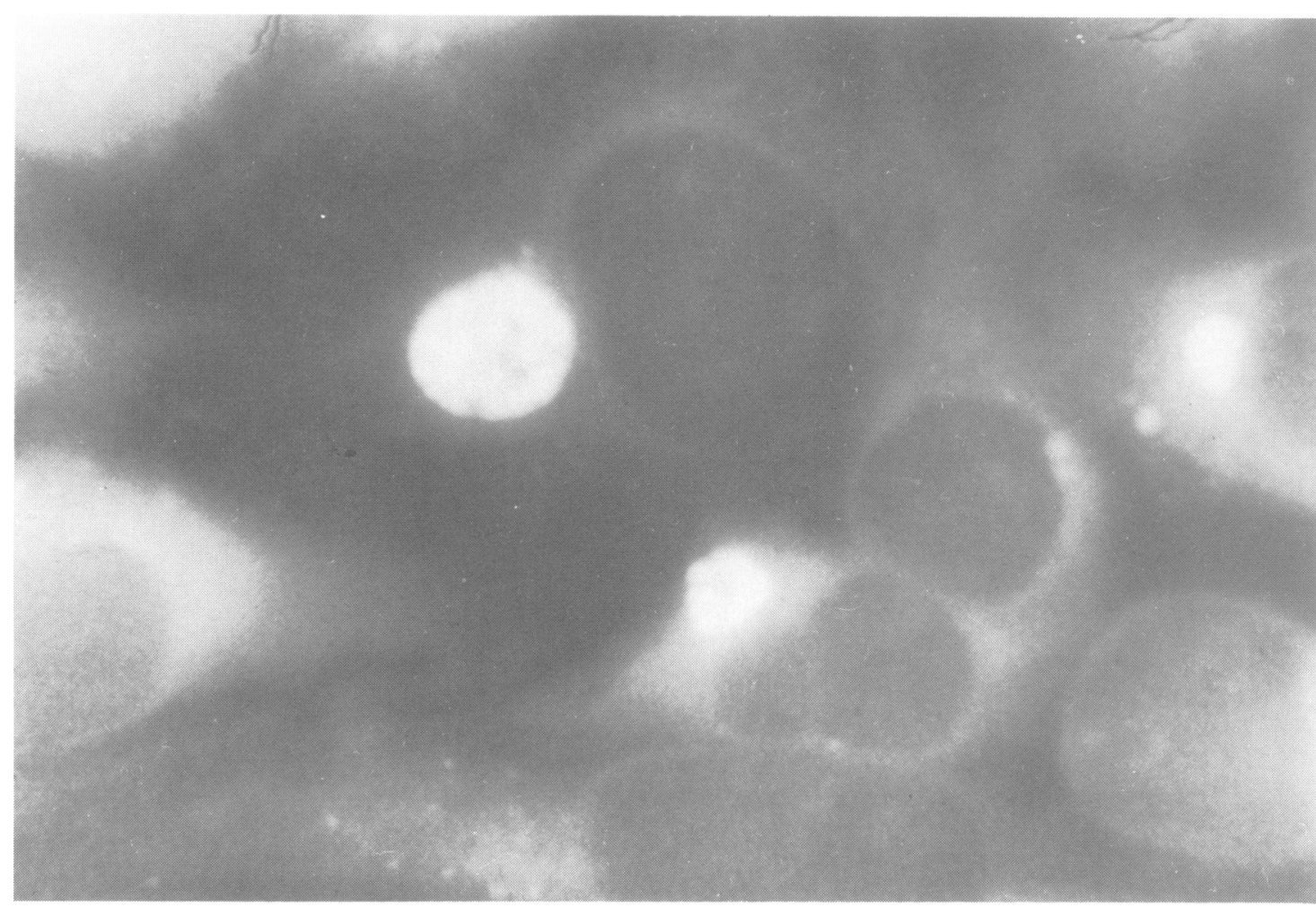

FIG 3 Ovarian homogenate cultivated for Chlamydia trachomatis in McCoy cells. Immunofluorescent staining of inclusion bodies $\times 1000$.

endocervical or endometrial material was excluded. As is shown in table II the only important microbial isolated was $C$ trachomatis. To our knowledge there is no previously recorded case of direct ovarian infection with $C$ trachomatis, or a case in which secondary amenorrhoea was reversed by aggressive antibiotic treatment. We suggest that the hormonal aberrations that developed during the 10-year interval before the laparoscopy may have been partly due to an infectious process in the ovaries and in the endometrial lining. In addition to menstrual abnormalities the patient had also lost numerous pregnancies (table I). The prompt resolution of her menstrual abnormalities and the subsequent pregnancy after successful antibiotic treatment suggest the possibility that infection with $C$ trachomatis could have been a factor in this woman's infertility. Further observations are needed on infertile women with secondary amenorrhoea. In these patients laparascopic ovarian biopsy and subsequent culture for $C$ trachomatis will provide a better understanding of the frequency and importance of this condition.

\section{References}

1. Swartz SL, Kraus SJ, Herrmann KL, Stagel MD, Brown WJ, Allen SD. Diagnosis and etiology of nongonococcal urethritis $J$ Infect Dis 1978; 139:445-54.

2. Mårdh P-A, Ripa KT, Wang S-P, Weström L. Chlamydia trachomatis as an etiological agent in acute salpingitis. In: Hobson D, Holmes KR, eds. Nongonococcal Urethritis and Related Infections. Washington DC: American Society for Microbiology, 1977:77-83.

3. Paavonen J, Saikku P, Vesterinen E, Aho K. Chlamydia trachomatis in acute salpingitis. Br J Vener Dis 1975; 55:203-6.

4. Gump DW, Dickstein S, Gibson M. Endometritis related to Chlamydia trachomatis infection. Ann Int Med 1981;95:61-3.

5. Dalaker K, Gjonnaess H, Kvile G, Urnes A, Anestad G, Bergan T. Chlamydia trachomatis as a cause of acute perihepatitis associated with pelvic inflammatory disease. $\mathrm{Br} \mathrm{J}$ Vener Dis 1981;57:41-3.

6. Schachter J, Dawson CT. Psittacosis-lymphogranuloma venereum agents TRIC agent. In: Lennette EH, Schmidt. NJ. eds. Diagnostic Procedures for Viral, Rickettsial and Chlamydial Infections. 5th ed. Washington DC: American Public Health Association, 1979: 1021-59.

7. Toth A, Swenson CE, O'Leary WM. Light microscopy as an aid in predicting ureaplasma infection in human semen. Fertil Steril 1978; 30: 586-9. 